\title{
FOCAL MYOCARDITIS IN PROFESSONAL FEMALE ATHLETE: A CASE REPORT
}

Nikola Cikiriz ${ }^{1}$, Marija Zdravkovic ${ }^{2}$, Stefan Simovic ${ }^{3}$, Vladimir Zivkovic ${ }^{4}$, Biljana Jakovljevic ${ }^{5}$, Sasa Hinic ${ }^{2}$, Ruzica Maksimovic ${ }^{6}$, Ivan Srejovic ${ }^{4}$ and Vladimir Jakovljevic ${ }^{4}$

${ }^{1}$ Department of Exercise Physiology, Institute of Hygiene, Military Medical Academy, Belgrade, Serbia

${ }^{2}$ University Hospital Medical Center "Bezanijska Kosa", Faculty of Medicine, University of Belgrade, Belgrade, Serbia

${ }^{3}$ Clinic for Cardiology, Clinical Center Kragujevac, Kragujevac, Serbia

${ }^{4}$ University of Kragujevac, Faculty of Medical Sciences, Department of Physiology, Kragujevac, Serbia

${ }^{5}$ Medical College of applied sciences in Zemun, University of Belgrade, Belgrade Serbia

${ }^{6}$ Institute of Radiology, Clinical Center Serbia, Faculty of Medicine, University of Belgrade, Belgrade, Serbia

FOKALNI MIOKARDITIS KOD PROFESIONALNE ATLETIČARIE:

PRIKAZ SLUČAJA

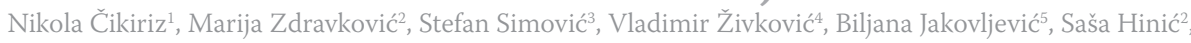
Ružica Maksimović́, Ivan Srejovićs i Vladimir Jakovljevićt

${ }^{1}$ Odsek za praktičnu fiziologiju, Institut za medicinsku higijenu, Vojno-medicinska akademija, Beograd, Srbija

${ }^{2}$ Univerzitetski kliničko-bolnički centar "Bežanijska Kosa", Medicinski fakultet, Univerzitet u Beogradu, Beograd, Srbija

${ }^{3}$ Klinika za kardiologiju, Klinički centar Kragujevac, Kragujevac, Srbija

${ }^{4}$ Katedra za fiziologiju, Fakultet medicinskih nauka, Univerzitet u Kragujevcu, Kragujevac, Srbija

${ }^{5}$ Visoka zdravstvena škola strukovnih studija u Zemunu, Univerzitet u Beogradu, Beograd, Srbija

'Institut za radiologiju, Klinički centar Srbije, Medicinski fakultet, Univerzitet u Beogradu, Beograd, Srbija

Received / Primljen: 30. 10. 2017

Accepted / Prihvaćen: 13. 11. 2017.

\section{ABSTRACT}

A 35-year-old female athlete appealed to her sports physician on new onset of frequent palpitations, just before an important competition. Initial electrocardiography revealed unifocal premature ventricular complexes in the form of bigeminy. Echocardiography revealed fine-granulated hyperdensic changes in septum. Global strain rate was within a range normal, as well as pulsed tissue Doppler ultrasound. Patient was referred for cardiac MRI, which revealed interventricular septum with rougher compounds, but with preserved continuity, with thickness of $10 \mathrm{~mm}$, which is in the middle of the $L V$, in length of $5 \mathrm{~mm}$, thinned to a thickness of $4 \mathrm{~mm}$. ELISA laboratory test demonstrated an increased titer of IgM antibodies for adenovirus. Six months later, the patient was referred for control MRI of the heart, which showed pronounced trabeculation of infero-lateral wall of the left ventricle, but without certain criteria for non-compaction cardiomyopathy. There was T1 oedema component in apical septal segment and apical segment of the left ventricle. There was increase of the signal in late gadolinium enhancement in the medial parts of the same segments but also in the segment of the basomedial septum, with previous focal myocarditis. These findings suggest myocardial fibrosis in the segments that were stricken by myocarditis, now without active ongoing myocarditis, but without consequent myocardial fibrosis.

Keywords: focal myocarditis, sudden cardiac death, athlete, cardiac MRI

\section{SAŽETAK}

Sportistkinja, starosti 35 godina, se javila svom sportskom lekaru zbog osećaja čestih palpitacija, neposredno pre početka važnog takmičenja. Inicijalnom elektrokardiografijom je utvrđeno postojanje unifokalnih preuranjenih ventrikularnih kompleksa po tipu bigeminije. Ehokardiografskim pregledom su uočene finogranulirane, hiperdenzične promene u septumu. Globalni strain rate (naprezanje miokarda u jedinici vremena) je bio u okviru fizioloških vrednosti, kao i vrednosti pulsnog tkivnog Doppler ultrazvuka. Pacijent je podvrgnut MRI ispitivanju srca, čime je otkriveno postojanje grubljeg sadržaja u intervetrikularnom septumu, koji je bio nepromenjenog kontinuiteta $i$ debljine $10 \mathrm{~mm}$, koja se u sredini leve komore u dužini od 5 mm smanjila na $4 \mathrm{~mm}$. ELISA testom je pokazano povećanje titra IgM antitela na adenoviruse. Šest meseci kasnije uraden je kontrolni MRI pregled srca, na kome je uočena izražena trabekulacija infero-lateralnog zida leve komore, ali bez dovoljno kriterijuma za dijagnozu nekompaktne kardiomiopatije. Takode, postojala je T1 komponeta edema apikalnih delova septuma $i$ leve komore. Postojalo je pojačanje signala uz upotrebu gadolinijuma u medijalnim delovima istih segmenata, ali i u segmentu bazomedialnog septuma, sa prethodnim fokalnim miokarditisom. Ovi nalazi sugerišu fibrozu miokarda u segmentima koji su pogodeni miokarditisom, sada bez aktivnog miokarditisa, ali bez posledične fibroze miokarda.

Ključne reči: fokalni miokarditis, iznenadna srčana smrt, sportisti, MRI srca

\section{ABBREVIATIONS}

ARVC- Arrhythmogenic right ventricular cardiomyopathy ECG - Electrocardiogram LGE - Late gadolinium enhancement LV - Left ventricle

MRI - Magnetic resonance imaging
MSCT - Multislice computed tomography

nsVT - Non-sustained ventricular tachycardia

PVC - Premature ventricular complexes

RV - Right ventricle

SCD - Sudden cardiac death

SPECT - Single positron emission computed tomography 


\section{INTRODUCTION}

Athletes are often perceived as the healthiest portion of the society; however, they are not exempt from sudden cardiac death (SCD). Furthermore, athletes with cardiovascular abnormalities are at greater risk of SCD compared with their non-athletic counterparts (1). Those cardiovascular abnormalities represent a substrate for the development of ventricular arrhythmias that lead to SCD. The most important cause of SCD in athletes older than 35 years coronary artery disease while in the athletes younger than 35 years, the most common cause of the SCD are hypertrophic and dilated cardiomyopathy, arrhythmogenic right ventricular cardiomyopathy (ARVC), electrical cardiac abnormalities (such as Wolf-Parkinson-White syndrome, long QT syndromes and Brugada syndrome) and acquired cardiac abnormalities, such as myocarditis and performance-enhancing drugs (2-3).

Identification of athletes with potentially serious cardiac diseases plays an important role. Pre-participation screening with a 12-lead electrocardiogram (ECG) is effective and may rise suspicion for cardiomyopathies (4). Organizations and sports governing bodies, such as European Society of Cardiology, American Heart Association and International Olympic Committee are positive in the attitude of the obligatory pre-participation cardiovascular screening (5-7). However, not all causes of SCD can be excluded with pre-participation screening, whereas we are still witnessing tragic SCD.

Myocarditis, an inflammation of the myocardium, is one of the major causes of sudden unexpected death in athletes - children and young adults (8). This inflammation may cause acute heart failure and life-threatening arrhythmias (9). Regarding an increased risk of SCD and development of dilated cardiomyopathy (10-11), myocarditis is one of the most challenging diagnoses in cardiology, often due to broad spectrum of its clinical presentation, which overlaps with other cardiac diseases (12). Viral infections of the myocardium are the most common, with up to more than 50 well known cardiotropic viruses, while the most frequent are adenoviruses, enteroviruses and herpes viruses (12). Not so rarely, myocarditis can be also caused by other, not specifically cardiotropic viruses, e.g. H1N1 virus (13).

\section{CASE REPORT}

A 35-year-old female athlete appealed to her sports physician on new onset of frequent palpitations, just before an important competition. Previous medical history was clear, as well as family history on cardiovascular diseases and SCD. In the months preceding the symptoms, she stated that there were no signs of infection of the respiratory and gastrointestinal system, but she has had occasional palpitations even for more than 6 months, not paying attention to them until the moment.



Figure 1. VTns during 24-hour Holter ECG monitoring, indicating origin between anterior and posterior fasciculus of left branch of Hiss bundle. septum and ventricular apex.

Initial electrocardiography revealed unifocal premature ventricular complexes (PVC) in the form of bigeminy and she was immediately referred to the cardiologist. All initial laboratory parameters, markers of inflammation and myocardial necrosis were within normal range. Echocardiography revealed fine-granulated hyperdensic changes in septum, with pericardial adhesions in the region of the posterior wall, without pleural effusion and without segmental and global kinetic disorders, with preserved systolic and diastolic function of the left and right ventricle (LV and RV), with normal flow at all cardiac confluences. Global strain rate was within a range normal, as well as pulsed tissue Doppler ultrasound on the medial and lateral sides of the mitral and tricuspid valves. Right ventricle was without pathological signs of ARVC. Stress test on a treadmill revealed normal coronary reserve, without presence of ischemic heart disease, but in the recovery period, there was the emergence of a large number of uniform PVCs, especially in the form of bigeminy. 24-hour Holter ECG monitoring revealed presence of a large number of isolated PVCs, approximately 200 episodes of ventricular bigeminy and trigeminy and 1 episode of non-sustained ventricular tachycardia (nsVT) with 4 QRS complexes, during sleep. All the above-mentioned PVCs were uniformed, in the term of morphology and pointed out that the origin was from right ventricular outflow tract. However, the episode of nsVT during sleep was not as same morphology as PVCs, but indicated the origin between the anterior and posterior fasciculus of left branch of Hiss bundle (Figure 1.).

After initial clinical examination and standard cardiology treatment, patient was referred for cardiac MRI, which revealed interventricular septum with rougher compounds, but with preserved continuity, with thickness of $10 \mathrm{~mm}$, which is in the middle of the $\mathrm{LV}$, in length of $5 \mathrm{~mm}$, thinned to a thickness of $4 \mathrm{~mm}$ (Figure 2.). LV had normal morphological characteristics (end-diastolic diameter of $55 \mathrm{~mm}$ and end-systolic diameter of $36 \mathrm{~mm}$ ), without regional contractility disorders and normal systolic function (ejection fraction of left ventricle $62 \%$, end-diastolic volume of left ventricle $198 \mathrm{ml}$ and end-systolic volume of left ventricle $75 \mathrm{ml})$. RV also had normal morphological characteristics and systolic function. 

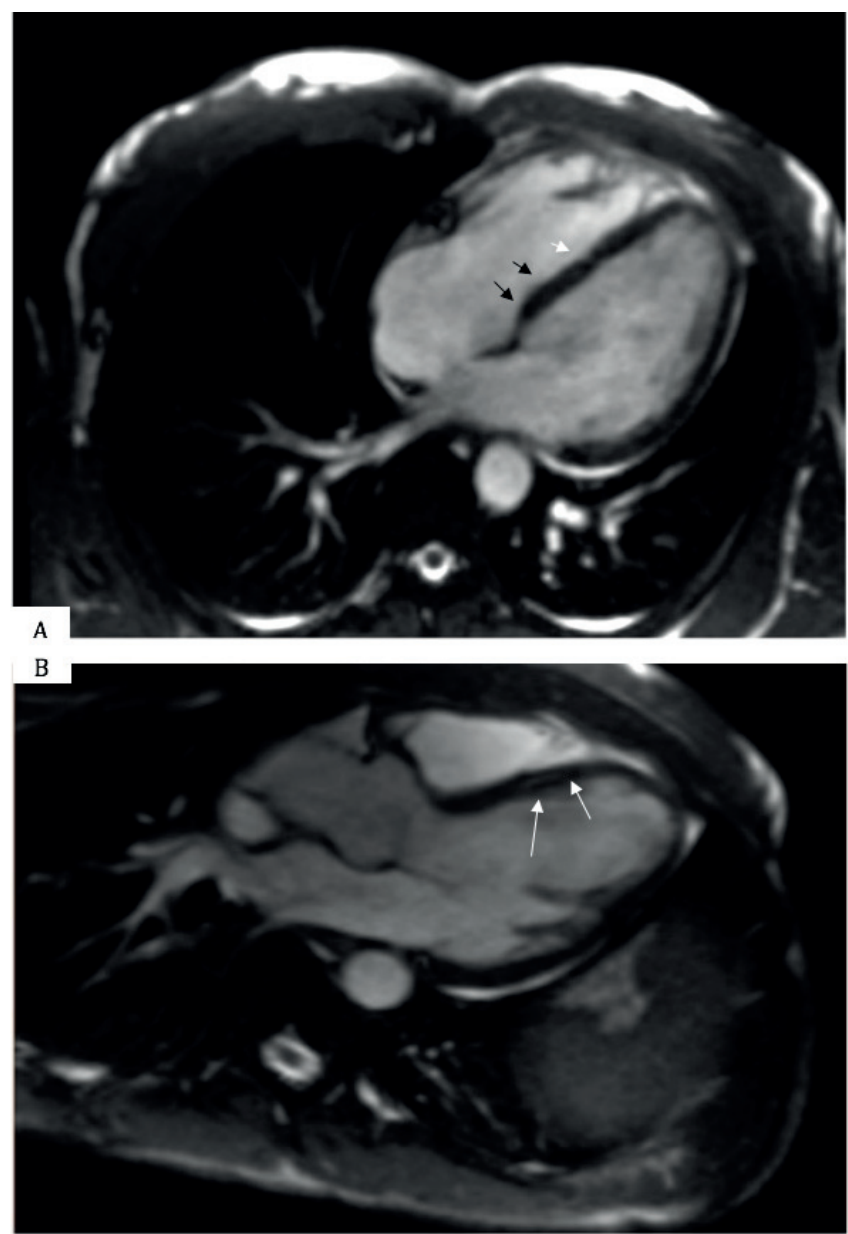

Figure 2. Cardiac MRI. Figure 2A - Four chamber cardiac MRI showing interventricular septum with rough compounds (black arrows), with thickness of $10 \mathrm{~mm}$. Thinned interventricular septum is in the middle of LV (white arrows). Figure 2B - Post-contrast T1-weighted delayed midwall septal hyperenhancement (white arrows).

ELISA laboratory test demonstrated an increased titer of IgM antibodies for adenovirus (1.12 with cut-off value of $<0.8)$, confirmed by repeated testing.

Treatment was initiated with low dose of beta-blockers in addition to vitamin and mineral supplementation, as well as coenzyme Q10. She was advised to rest and not to make physical effort in the preceding months. The athlete was in daily contact with her team physician. After 2 weeks she felt better, exercise testing was performed and there was significantly smaller number of PVCs, while inflammatory syndrome was normal.

Six months later, she was subjected to the control echocardiography, which showed bright laminar and grainy echoes in the interventricular septum, while there were no other significant differences in the echo-morphology and functional testing of the heart. 24-hour ECG Holter monitoring showed few PVCs, without episodes of nsVT. Subsequently, the patient was referred for control MRI of the heart, which showed pronounced trabeculation of infero-lateral wall of the left ventricle, but without certain criteria for non-compaction cardiomyopathy. There was T1 oedema component in apical septal segment and api- cal segment of the left ventricle (Figure 3.). After the delivery of contrast, there was increase of the signal in late gadolinium enhancement (LGE) in the medial parts of the same segments but also in the segment of the basomedial septum, with previous focal myocarditis (Figure 4.). These findings suggest myocardial fibrosis in the segments that were stricken by myocarditis, now without active ongoing myocarditis, but without consequent myocardial fibrosis.

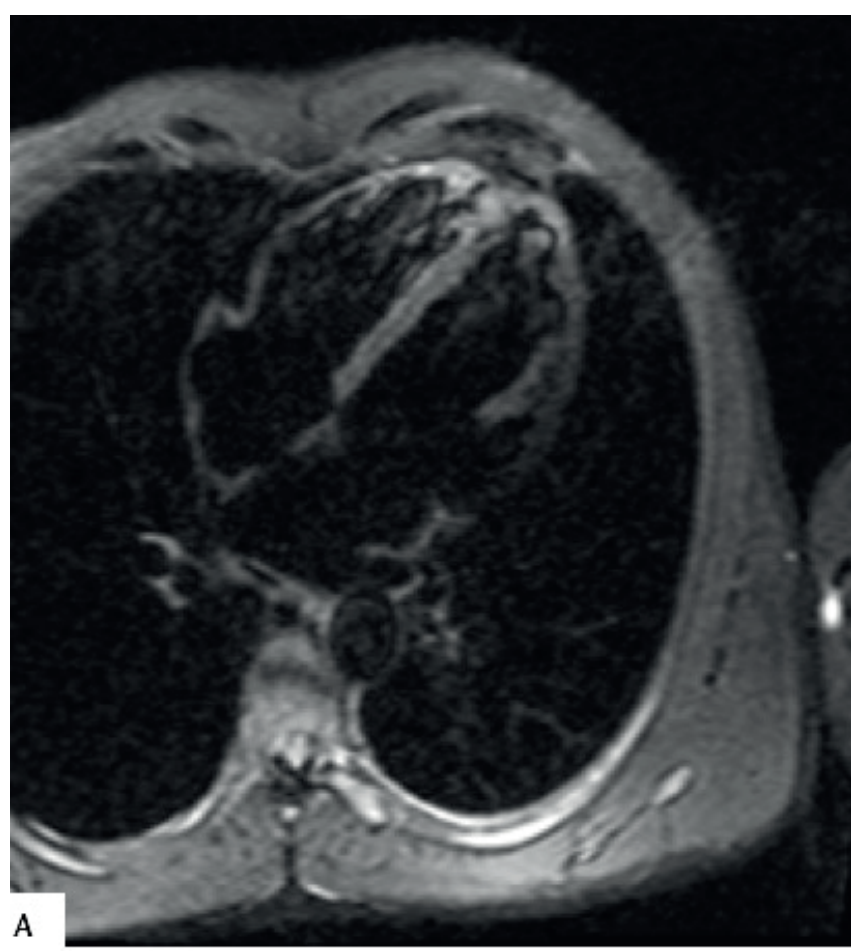

B

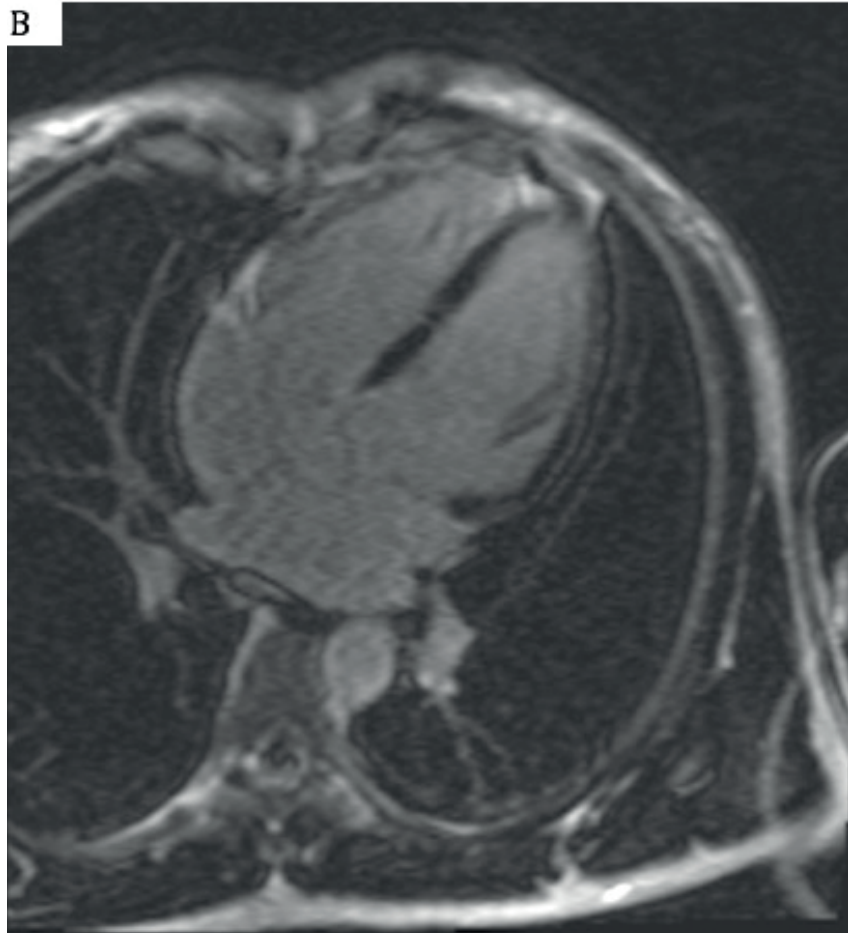

Figure 3. Control cardiac MRI after 6 months. Figure 3A -STIR sequences in septum and the apex. Figure 3B - LGE phenomenon in basomedial 
Today, almost a year since the initial event, the patient is feeling good, without any symptoms, she returned to training, but she is under intensive medical supervision because of possible complications in terms of repetitive myocarditis.

\section{DISCUSSION}

Current concept of focal myocarditis as an incidental finding is not well established. It is known that small inflammatory foci with necrosis occurs in less than $5 \%$ of the autopsied hearts, and is likely a contributing factor in cases od unexplained sudden death (14). However, not all focal myocarditis result in unexplained sudden death. Even though often asymptomatic, a large portion of patients presents with clinical presentation of acute coronary syndrome, new-onset of heart failure and life-threatening arrhythmias (12). Among arrhythmias, most frequent are PVCs, ventricular fibrillation/flutter and sustained ventricular tachycardia.

The significance of focal myocardial inflammation in sudden death is not well established, since there are few studies addressing its frequency in cardiac and non-cardiac arrhythmic death (14). Besides, diagnosis of focal myocarditis can be extremely difficult using conventional techniques such as electrocardiography, echocardiography and standard laboratory tests (15). Nevertheless, detailed anamnesis and clinical examination combined with standard diagnostic techniques (ECG, echocardiography and laboratory tests) may arouse suspicion on focal myocarditis. Endomyocardial biopsy identifies the inflammation markers only in patients with extensive myocarditis (16). Further noninvasive cardiac methods, such as multislice computed tomography (MSCT), single positron emission computed tomography (SPECT) and magnetic resonance imaging (MRI) have been proposed to detect foci of myocarditis (17).

In recent years, MRI has been identified as important diagnostic tool in differential diagnosis of patients with suspected myocarditis, especially in young patients (18). LGE and T2-weighted MRI images are currently crucial diagnostic criteria for defining a focal myocardial injury, however, they are typically compared to the normal appearing myocardium as a reference for diagnosis of myocarditis (19-20). This often leads to errors since intensity and distribution of inflammatory infiltrates are highly variable (21-22). Also, LGE signal differs from one study to another, it is influenced by technical parameters, including the threshold set for differentiation of normal vs. fibrotic myocardium (23). In search for assessment of myocardial injury without need for arbitrarily defined reference tissue, T1 and T2 MRI mapping are emerging (24). Recent studies showed that these mapping techniques can improve diagnostic value of MRI in patients with suspected myocarditis (25). In the study of Radunski et al (18), they even showed that the amount of myocardial injury assessed by LGE imaging was underestimated, as well as that $\mathrm{T} 2$ values in nor- mal appearing myocardium were altered to a lesser degree compared to the native $\mathrm{T} 1$ and values of extracellular volume fraction. In addition, Ferreira et al (26), demonstrated the value of native T1 mapping to asses' focal myocardial injury in patients with myocarditis.

The significant cost of MRI and logistical limitation is keeping away its integration into the routine pre-participation. Although, there are proofs that ECG screening can reduce the incidence of SCD in athletes (27), it has also been controversial (28). Despite evidences for incorporating ECG in standard pre-participation screening, American Heart Association does not support routine use of ECG and false positive results and cost-effectiveness are main arguments (2). In United States, a standard 12-channel ECG with symptoms, family history and physical examination is recommended, while in Italy, it is mandatory for all competitive athletes (2). One thing is certain, ECG provides information regarding electrical abnormalities of the heart and is also effective in identifying cardiomyopathy, however, some structural abnormalities may pass unnoticed. Therefore, structural assessment of the heart may have its role. Transthoracic echocardiography is the primary modality for cardiomyopathies and myocarditis, but small focal lesions, such as we have seen in our case report, may not necessarily be seen on echocardiography. That is why alternative modalities, such MRI, should be considered in selected individuals.

In general, pre-participation screening with detailed physical examination with family history and symptoms as well as standard, 12-channel ECG can provide sufficient information and arouse suspicion for cardiac abnormalities that could lead to SCD in athletes. In addition, echocardiography and cardiac MRI can readily examine morphology and function and could lead to timely initiation of the treatment which is crucial.

\section{CONCLUSION}

Here, we present an interesting case report of a young female athlete with focal myocarditis caused by adenoviral infection. Although echocardiography even with advanced techniques (pulsed Doppler tissue imaging and strain rate) did not point out a possible cause, cardiac MRI revealed focal, inflammatory lesion in the interventricular septum and inflammatory modulation has been confirmed by ELISA test. It is also notable, that prompt diagnosis and treatment in this case lead to the rapid recovery of the patient and not to possible and tragic SCD.

\section{REFERENCES}

1. Corrado D, Basso C, Rizzoli G, Schiavon M, Thiene G. (2003). Does sports activity enhance the risk of sudden death in adolescents and young adults? J Am Coll Cardiol, 42:1959-63. 
2. Chandra N, Bastienen R, Papadakis M, Sharma S. (2013). Sudden Cardiac Death in Young Athletes. Practical Challenges and Diagnostic Dilemmas. J Am Coll Cardiol, 61 (10): 1027-1040.

3. Zdravkovic M, Krotin M. (2009). Right ventricular noncompacted cardiomyopathy-time for a new classification? Chin Med J (Eng), 122 (23):2920.

4. Dhutia H, Malhora A, Gabus V, et al. (2016). Cost Implications of Using Different ECG Criteria for Screening Young Athletes in the United Kingdom. J Am Coll Cardiol, 68 (7): 702-711.

5. Ljungqvist A, Jenoure P, Engebretsen L, et al. (2009). The International Olympic Committee (IOC) Consensus Statement on periodic health evaluation of elite athlete's March 2009. Br J Sports, 43: 631-43.

6. Corrado D, Pelliccia A, Bjornstad HH, et al. (2005). Cardiovascular preparticipation screening of young competitive athletes for prevention of sudden death: proposal for a common European protocol. Eur Heart J, 26: 516-24.

7. Maron BJ, Thompson PD, Ackerman MJ, et al. (2007). Recommendations and considerations related to preparticipation screening for cardiovascular abnormalities in competitive athletes: 2007 update. Circulation, 115:1643-55.

8. Drory Y, Turetz Y, Hiss Y et al. (1991). Sudden unexpected death in persons less than 40 years of age. Am J Cardiol, 68:1388-92.

9. Anzini M, Merlo M, Sabbadini G, et al. (2013). Long-term evolution and prognostic stratification of biopsy-proven active myocarditis, Circulation, 128 (22): 2384-2394.

10. Basso C, Calabrese F, Corrado D, Thiene G. (2011). Postmortem diagnosis in sudden cardiac death victims: macroscopic, microscopic and molecular findings, Cardiovasc Res, 50 (2): 290-300.

11. D’Ambrosio A, Patti G, Manzoli A, et al. (2001). The fate of acute myocarditis between spontaneous improvement and evolution to dilated cardiomyopathy: a review, Heart, 85 (5): 499-504.

12. Biesbroek PS, Beek AM, Germans T, Niessen HWM, van Rossum AC. (2015). Diagnosis of myocarditis: Current state and future perspectives. Int J Cardiol, 191: 211-219.

13. Davidovic G, Simovic S, Mitrovic S, Iric-Cupic V, Miloradovic V. (2016). Fulmminant myocarditis as a primary manifestation of $\mathrm{H} 1 \mathrm{~N} 1$ infection. A first reported case from Serbia. Hell J of Cardiol, 57 (3): 181-184.

14. Zhang M, Tavora F, Zhang Y, Ripple M, Fowler D, Li L, Zhao Z, Burke A. (2013). The role of focal myocardial inflammation in sudden unexpected cardiac and noncardiac deaths-A clinicopathological study. Int J Legal Med, 127: 131-138.

15. Theleman KP, Kuiper JJ, Roberts WC. (2001). Acute myocarditis sudden death without heart failure. Am J Cardiol, 88:1078-83.

16. Lie JT. (1988). Myocarditis and endomyocardial biopsy in unexplained heart failure: a diagnosis in search of a disease. Ann Intern Med, 109: 525-8.
17. Di Bella G, Gregorio C, Minutoli F, Pingitore A, Coglitore S, Arrigo F, Carerj S. (2007). Early diagnosis of focal myocarditis by cardiac magnetic resonance. Int J Cardiol, 117: 280-281.

18. Radunski UK, Lund GK, Saring D, Bohen S, Stehning C, Schnackenburg B, et al. (2016). T1 and T2 mapping cardiovascular magnetic resonance imaging techniques reveal unapparent myocardial injury in patients with myocarditis. Clin Res Cardiol, 106 (1): 10-17.

19. Friedrich MG, Sechtem U, Schulz-Menger J, et al. (2009). Cardiovascular magnetic resonance in myocarditis: a JACC white paper. J Am Coll Cardiol, 2053(17):1475-1487.

20. Vermes E, Childs H, Carbone I, Barckow P, Friedrich MG. (2013). Auto-threshold quantification of late gadolinium enhancement in patients with acute heart disease. J Magn Reson Imaging, 37(2):382-390.

21. Friedrich MG, Strohm O, Schulz-Menger J, Marciniak H, Luft FC, Dietz R. (1998). Contrast media-enhanced magnetic resonance imaging visualizes myocardial changes in the course of viral myocarditis. Circulatio, 97(18):1802-1809.

22. Basso C, Calabrese F, Angelini A, Carturan E, Thiene G. (2013). Classification and histological, immunohistochemical, and molecular diagnosis of inflammatory myocardial disease. Heart Fail Rev, 18(6):673-681.

23. Waterhouse DF, Ismail TF, Prasad SK, Wilson MG, O'Hanlon R. (2012). Imaging focal and interstitial fibrosis with cardiovascular magnetic resonance in athletes with left ventricular hypertrophy: implications for sporting participation. Br J Sports Med, 46 (Suppl I):i69-i77.

24. Ferreira VM, Piechnik SK, Robson MD, Neubauer S, Karamitsos TD. (2014). Myocardial tissue characterization by magnetic resonance imaging: novel applications of T1 and T2 mapping. J Thorac Imaging, 29(3):147-154

25. Bohnen S, Radunski UK, Lund GK, et al. (2015). Performance of $\mathrm{t} 1$ and $\mathrm{t} 2$ mapping cardiovascular magnetic resonance to detect active myocarditis in patients with recent-onset heart failure. Circ Cardiovas Imaging 8(6). doi:10.1161/CIRCIMAGING.114.003073

26. Ferreira VM, Piechnik SK, Dall'Armellina E, et al. (2014). Native T1-mapping detects the location, extent and patterns of acute myocarditis without the need for gadolinium contrast agents. J Cardiovas Magn Reson, 16:36. doi: 10.1186/1532-429X-16-36.

27. Corrado D, Basso C, Schiavon M, et al. (2008). Pre-participation screening of young competitive athletes for prevention of sudden cardiac death. J Am Coll Cardiol, 52:1981-9.

28. Steinvil A, Chundadze T, Zeltser D, et al. (2011). Mandatory electrocardiographic screening of athletes to reduce their risk for sudden death proven fact or wishful thinking? J Am Coll Cardiol, 57:1291-6. 